Article

\title{
A Comparative Study of Ferulic Acid on Different Monosaccharide-Mediated Protein Glycation and Oxidative Damage in Bovine Serum Albumin
}

\author{
Weerachat Sompong ${ }^{1}$, Aramsri Meeprom ${ }^{1}$, Henrique Cheng ${ }^{2}$ and Sirichai Adisakwattana ${ }^{3,4, *}$ \\ 1 Program in Clinical Biochemistry and Molecular Medicine, Department of Clinical Chemistry, \\ Faculty of Allied Health Sciences, Chulalongkorn University, Bangkok 10330, Thailand; \\ E-Mails: weerachat.tum@gmail.com (W.S.); meeprom.a@gmail.com (A.M.) \\ 2 Department of Comparative Biomedical Sciences, School of Veterinary Medicine, \\ Louisiana State University, Baton Rouge, LA 70803, USA; E-Mail: hcheng@vetmed.lsu.edu \\ 3 Research Group of Herbal Medicine for Prevention and Therapeutic of Metabolic Diseases, \\ Chulalongkorn University, Bangkok 10330, Thailand \\ 4 The Medical Food Research and Development Center, Department of Nutrition and Dietetics, \\ Faculty of Allied Health Sciences, Chulalongkorn University, Bangkok 10330, Thailand \\ * Author to whom correspondence should be addressed; E-Mail: sirichai.a@chula.ac.th; \\ Tel.: +66-2-218-1067; Fax: +66-2-218-1076.
}

Received: 9 October 2013; in revised form: 4 November 2013 / Accepted: 6 November 2013 / Published: 11 November 2013

Abstract: Three dietary monosaccharides, (glucose, fructose, and ribose), have different rates of protein glycation that accelerates the production of advanced glycation end-products (AGEs). The present work was conducted to investigate the effect of ferulic acid (FA) on the three monosaccharide-mediated protein glycations and oxidation of BSA. Comparing the percentage reduction, FA (1-5 mM) reduced the level of fluorescence AGEs (F-AGEs) and $\mathrm{N}^{\varepsilon}$-(carboxymethyl) lysine $\left(\mathrm{N}^{\varepsilon}\right.$-CML) in glucose-glycated BSA $\left(\mathrm{F}-\mathrm{AGEs}=12.61 \%-36.49 \% ; \mathrm{N}^{\varepsilon}\right.$-CML $\left.=33.61 \%-66.51 \%\right)$, fructose-glycated $\mathrm{BSA}$ $\left(\mathrm{F}-\mathrm{AGEs}=25.28 \%-56.42 \% ; \mathrm{N}^{\varepsilon}-\mathrm{CML}=40.21 \%-62.91 \%\right)$, and ribose-glycated BSA $\left(\mathrm{F}-\mathrm{AGEs}=25.63 \%-51.18 \% ; \mathrm{N}^{\varepsilon}-\mathrm{CML}=26.64 \%-64.08 \%\right)$. In addition, the percentages of FA reduction of fructosamine (Frc) and amyloid cross $\beta$-structure (Amy) were Frc = 20.45\%-43.81\%; Amy $=17.84 \%-34.54 \%$ in glucose-glycated BSA, Frc $=25.17 \%-36.92 \%$; Amy $=27.25 \%-39.51 \%$ in fructose-glycated BSA, and Frc $=17.34 \%-29.71 \%$; Amy $=$ $8.26 \%-59.92 \%$ in ribose-glycated BSA. FA also induced a reduction in protein carbonyl content (PC) and loss of protein thiol groups (TO) in glucose-glycated BSA 
$(\mathrm{PC}=37.78 \%-56.03 \% ; \mathrm{TO}=6.75 \%-13.41 \%)$, fructose-glycated BSA $(\mathrm{PC}=36.72 \%-52.74 \%$; $\mathrm{TO}=6.18 \%-20.08 \%)$, and ribose-glycated BSA $(\mathrm{PC}=25.58 \%-33.46 \% ; \mathrm{TO}=$ 20.50\%-39.07\%). Interestingly, the decrease in fluorescence AGEs by FA correlated with the level of $\mathrm{N}^{\varepsilon}$-CML, fructosamine, amyloid cross $\beta$-structure, and protein carbonyl content. Therefore, FA could potentially be used to inhibit protein glycation and oxidative damage caused by monosaccharides, suggesting that it might prevent AGEs-mediated pathologies during diabetic complications.

Keywords: protein glycation; oxidative damage; ferulic acid; monosaccharides; advanced glycation end-products (AGEs); comparative study

\section{Introduction}

Protein glycation is a non-enzymatic reaction between the carbonyl groups of monosaccharides such as glucose, fructose, and ribose with the amino groups of proteins. The reaction initiates a complex cascade of repeated condensations, rearrangements, and oxidative modifications resulting in the reversible formation of structures called Schiff's bases. This is followed by rearrangement to produce Amadori products like fructosamine [1,2]. Consequently, the Amadori products form cross-linked structures termed advanced glycation end-products (AGEs) [1-3]. AGEs can be classified into two major groups: fluorescent and crosslinking structures (pentosidine, crosslines, and imidazolones) and non-fluorescent and non-crosslinking structures ( $\mathrm{N}^{\varepsilon}$-(carboxymethyl)lysine, $\left.\mathrm{N}^{\varepsilon}-\mathrm{CML}\right)$ [4]. Accumulation of AGEs in body tissues plays a major role in the development of diabetic complications such as retinopathy, nephropathy, neuropathy, age-related diseases, atherosclerosis and Alzheimer's disease [5-8]. Interestingly, a number of studies report that the rate of protein glycation depends upon the concentration and type of monosaccharide that enhances the generation of AGEs $[9,10]$. In this regard, these occurrences increase the risk for developing complications related to diabetes. Recently, considerable attention has been devoted to the search for phytochemical compounds that inhibit protein glycation. These compounds could aid in the prevention of complications during diabetes.

Ferulic acid (FA) possesses many pharmacological effects, especially anti-diabetic activity [11-13]. Furthermore, it inhibits AGE formation in physiological and food model systems [13-15]. However, the ability of FA to inhibit protein glycation induced by different monosaccharides has not been evaluated. In the present study, we investigated the inhibitory effect of FA on three different types of monosaccharide-induced protein glycation and oxidative damage using a bovine serum albumin (BSA) in vitro model.

\section{Results and Discussion}

\subsection{Effect of Ferulic Acid on Advanced Glycation End-Products (AGEs) and Amadori Products}

As shown in Figure 1, the fluorescence intensity of AGEs in BSA incubated with three types of monosaccharides during four weeks significantly increased throughout the incubation period. At week 4, the fluorescence intensity of glucose-, fructose-, and ribose-glycated BSA was 10.71-, 17.22-, and 
77.23-fold higher than control non-glycated BSA. Protein glycation is a spontaneous reaction between monosaccharides and proteins that produces unstable Schiff bases that form Amadori products such as fructosamine, which is clinically used as an indicator for short-term control of blood sugars in diabetic patients $[1,2]$. This reaction generates irreversible heterogeneous products termed advanced glycation end products (AGEs) [2]. The rate of glycation is dependent on the concentration and type of monosaccharide [9,10]. All three monosaccharides exhibited protein cross-linking effects with different potency (glucose $<$ fructose $<$ ribose). Previous studies revealed faster accumulation of protein-bound fluorescence and oligomerization with fructose than glucose [16]. Moreover, the glycating ability of monosaccharides occur in the following increasing order: D-glucose $<$ D-mannose $<$ D-galactose $<$ D-xylose $<$ D-fructose $<$ D-arabinose $<$ D-ribose $<2$-deoxy-D-ribose [17]. The highest glycating capability of D-ribose is explained by its planar structure causing the unstable aldofuranose ring to react with the amino groups [10].

Figure 1. Time course of fluorescence intensity in BSA incubated with $500 \mathrm{mM}$ glucose (Glu), $500 \mathrm{mM}$ fructose (Fruc) or $100 \mathrm{mM}$ ribose (Rib). The results are expressed as mean $\pm \operatorname{SEM}(n=3) . * p<0.05$ when compared to BSA.

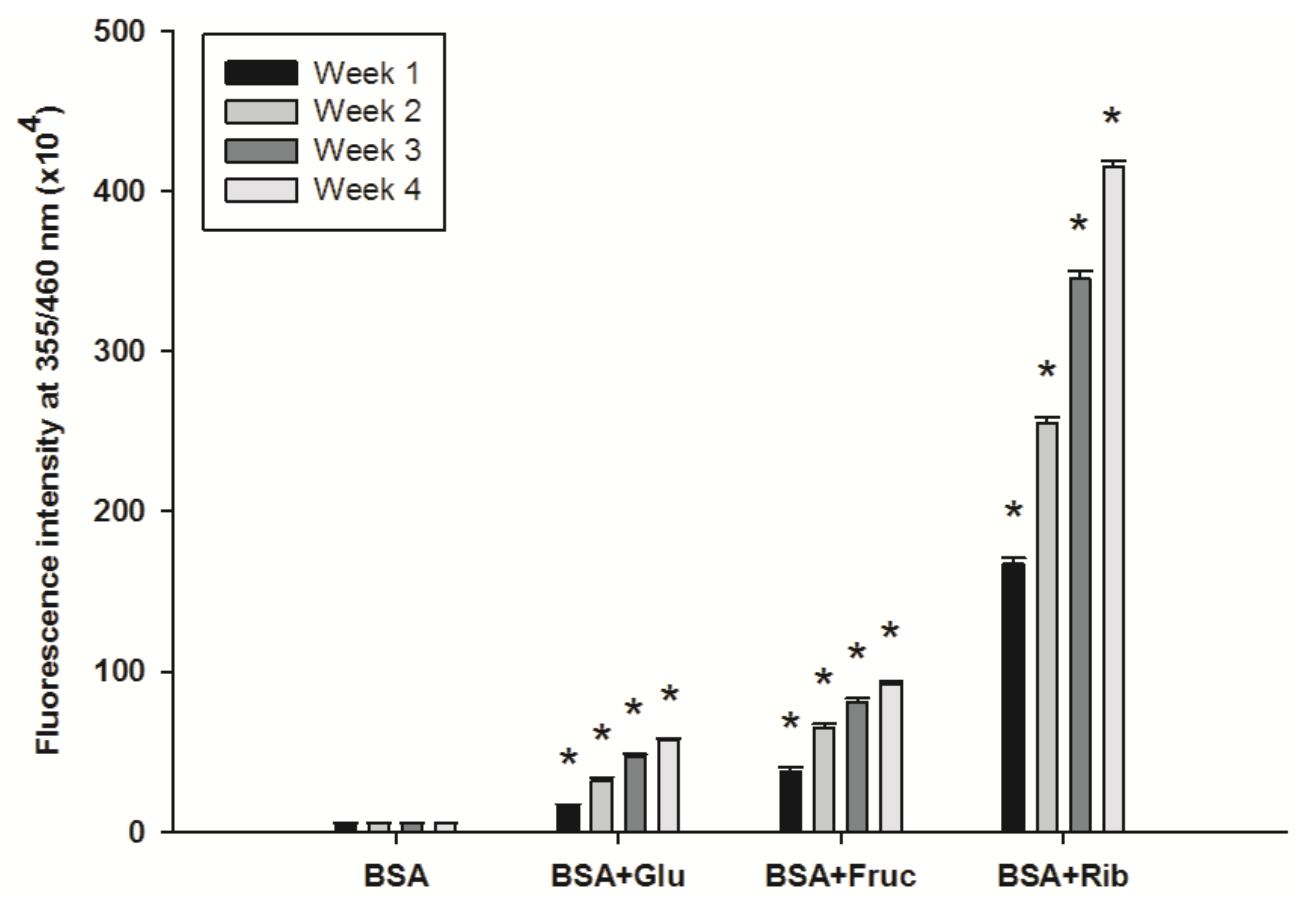

Figure 2 shows the effect of FA on fluorescent AGE formation in glycated BSA after four weeks of incubation. The addition of FA $(1,3$, and $5 \mathrm{mM})$ into the reaction mixtures significantly decreased the fluorescence intensity of glucose-glycated BSA (12.61\%, 21.70\%, and 36.49\%), fructose-glycated BSA $(25.28 \%, 41.79 \%$, and 56.42\%), and ribose-glycated BSA (25.63\%, 35.91\%, and 51.18\%). Furthermore, AG (1 mM) significantly decreased the fluorescence intensity of glucose-glycated BSA (33.81\%), fructose-glycated BSA (54.93\%), and ribose-glycated BSA (42.31\%). Comparing the percentages of reduction, FA inhibited more fructose-glycated BSA than glucose-glycated BSA. At the same concentration of $1 \mathrm{mM}$, the percentage inhibition of FA was less than AG in glucose-, fructose-, and ribose-glycated BSA. Silván et al. reported that FA markedly reduces the formation of $\mathrm{N}^{\varepsilon}-\mathrm{CML}$ and fluorescent AGEs during high fructose exposure [18]. Other studies revealed that lysine-524 is 
the major site of protein modification that leads to the loss of the corresponding unmodified tryptic peptide [19]. FA is also capable of binding to human serum albumin [20]. This binding causes structural changes and prevents BSA oxidation. Based on these findings, it can be hypothesized that FA binds to the same site of AGE formation in BSA that reduces glycation. Further studies are needed to test this hypothesis.

Figure 2. Effect of FA on the fluorescence intensity of BSA incubated with glucose (A), fructose $(\mathbf{B})$, and ribose $(\mathbf{C})$ at week 4 . The results are expressed as mean $\pm \operatorname{SEM}(n=3)$. $* p<0.05$ when compared to BSA, ** $p<0.05$ when compared to BSA+glucose, $\mathrm{BSA}+$ fructose or BSA+ribose. AG was used as positive control.

(A)

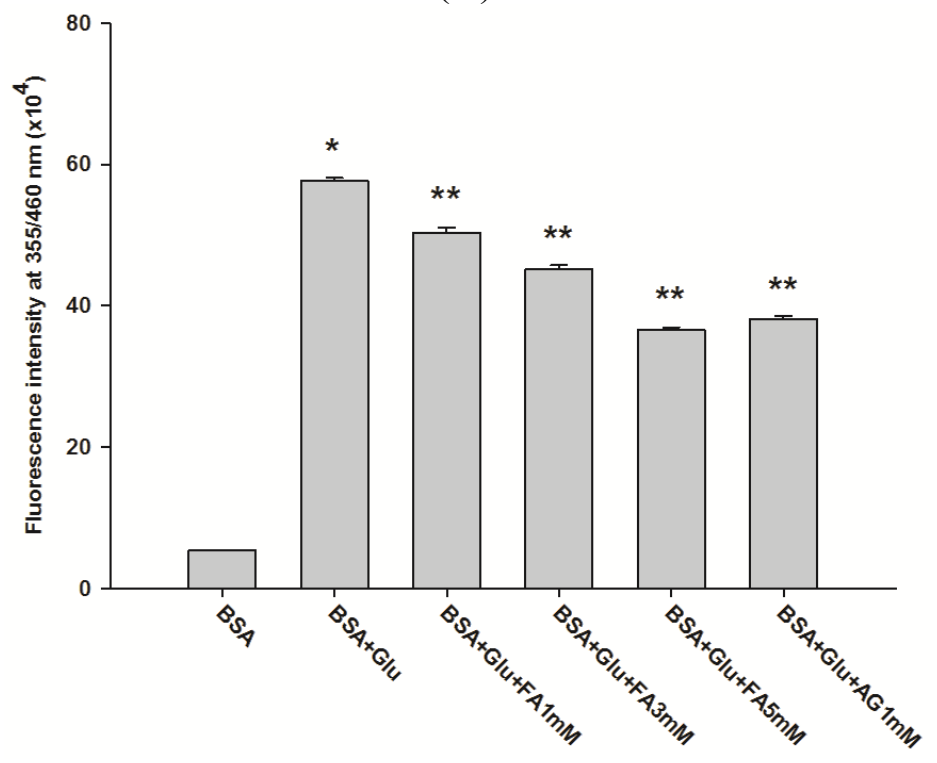

(B)

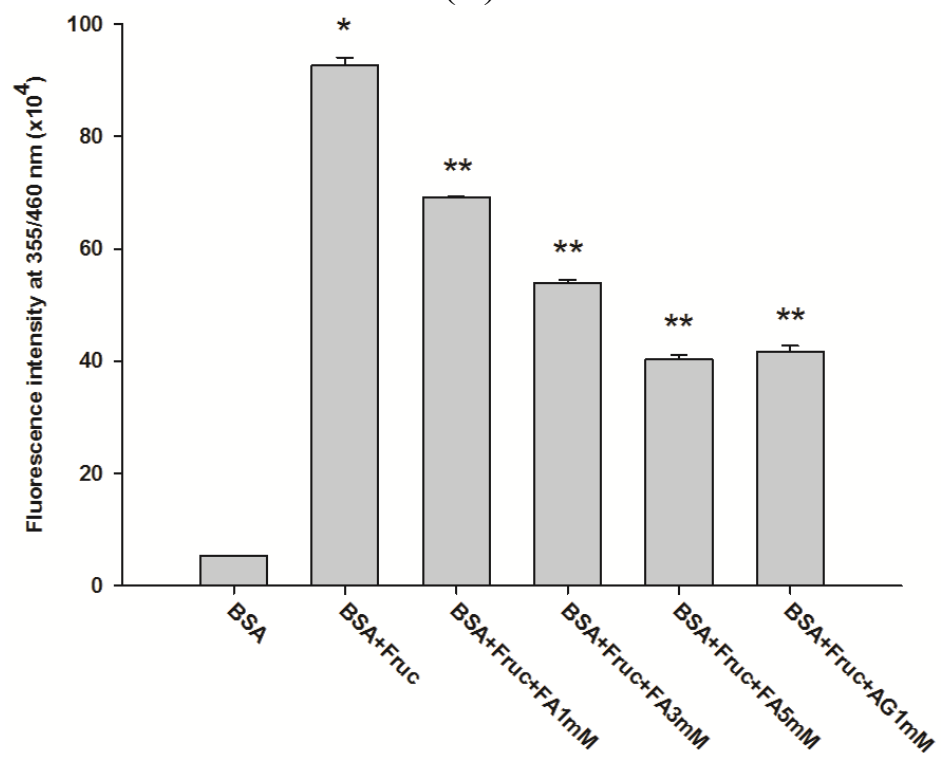


Figure 2. Cont.

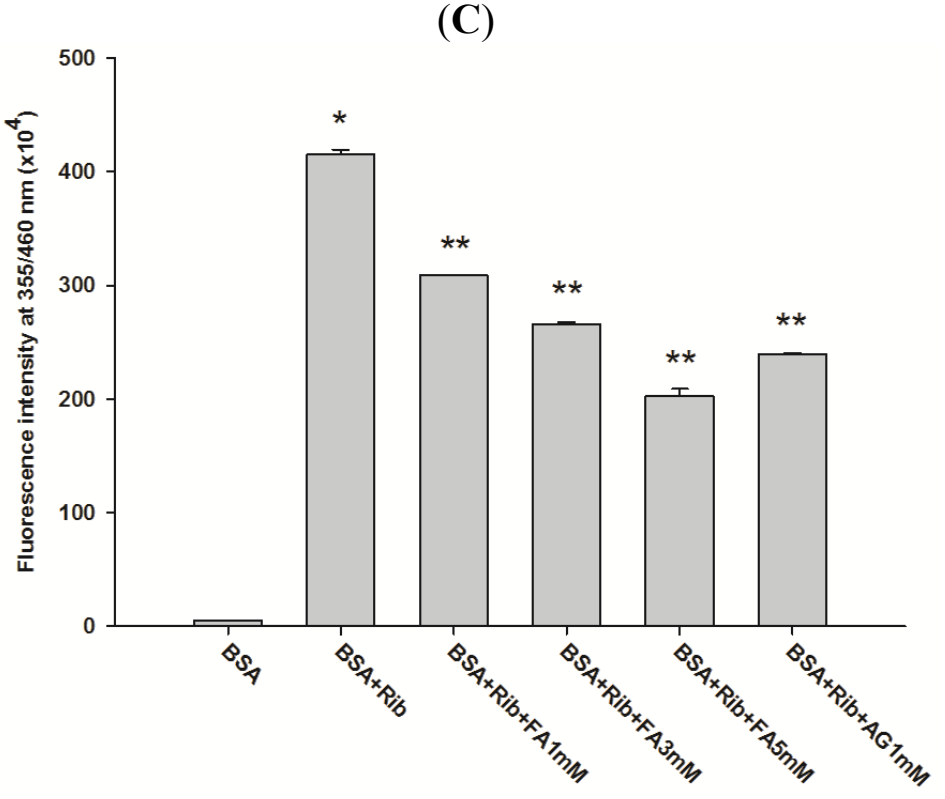

Cinnamic acid and its derivatives are widely present in the diet, serving as the most abundant source of antiglycation agent [21-23]. In a previous report, cinnamic acid was the most effective inhibitor against fructose-mediated protein glycation [21]. The ability to inhibit protein glycation of cinnamic acid derivatives is associated with the presence of hydroxy and methoxy substituents in their structures. Caffeic acid, a naturally occurring cinnamic acid, inhibits the formation of AGEs induced by methylglyoxal [22]. Nevertheless, caffeic acid also exhibits the pro-oxidative activity which facilitates the progress of protein glycation, thereby promoting the production of AGEs [23]. We have raised the possibility of a protective effect of isoferulic acid, an isomer of ferulic acid, in glucose- and fructose-mediated protein glycation. The results show that isoferulic acid can exert antiglycation activity in a concentration-dependent manner [24].

Figure 3 shows the effect of FA on $\mathrm{N}^{\varepsilon}$-CML level in glycated BSA after four weeks of incubation. The concentration of $\mathrm{N}^{\varepsilon}$-CML in glucose-, fructose-, and ribose-glycated BSA was 2.13-, 4.08- and 26.51-fold higher than non-glycated BSA. It was interesting to note that FA (1, 3, and $5 \mathrm{mM})$ significantly reduced the concentration of $\mathrm{N}^{\varepsilon}$-CML in glucose-glycated BSA $(33.61 \%, 45.84 \%$, and $66.51 \%)$, fructose-glycated BSA $(40.21 \%, 50.39 \%$, and $62.91 \%)$, and ribose-glycated BSA $(26.64 \%$, $51.05 \%$, and $64.08 \%$ ). These results suggest that FA can protect against advanced glycation end product formation. In addition, AG $(1 \mathrm{mM})$ decreased the concentration of $\mathrm{N}^{\varepsilon}$-CML in glucose-, fructose-, and ribose-glycated BSA by $44.44 \%, 46.62 \%$, and $34.83 \%$, respectively. The results indicate that the percentage inhibition of FA $(1 \mathrm{mM})$ was lower than the percentage inhibition of $A G(1 \mathrm{mM})$ in glucose, fructose-, and ribose-glycated BSA. 
Figure 3. Effect of FA on non-fluorescence AGEs level $\left(\mathrm{N}^{\varepsilon}-\mathrm{CML}\right)$ in BSA incubated with glucose (A), fructose $(\mathbf{B})$ and ribose $(\mathbf{C})$ at week 4 . The results are expressed as mean $\pm \operatorname{SEM}(n=3)$. ${ }^{*} p<0.05$ when compared to BSA, $* * p<0.05$ when compared to $\mathrm{BSA}+$ glucose, BSA+fructose or BSA+ribose. AG was used as positive control.

(A)

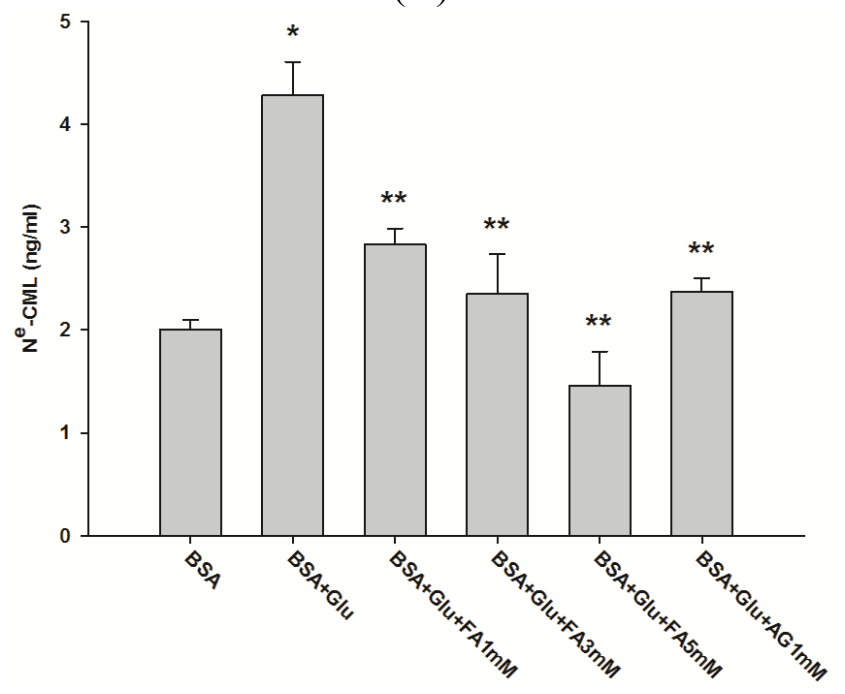

(B)

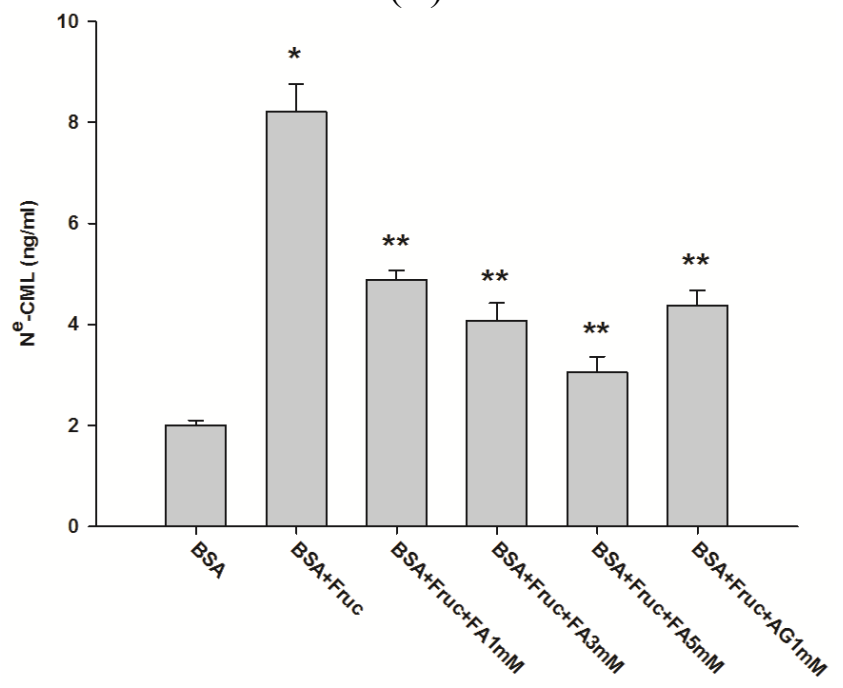

(C)

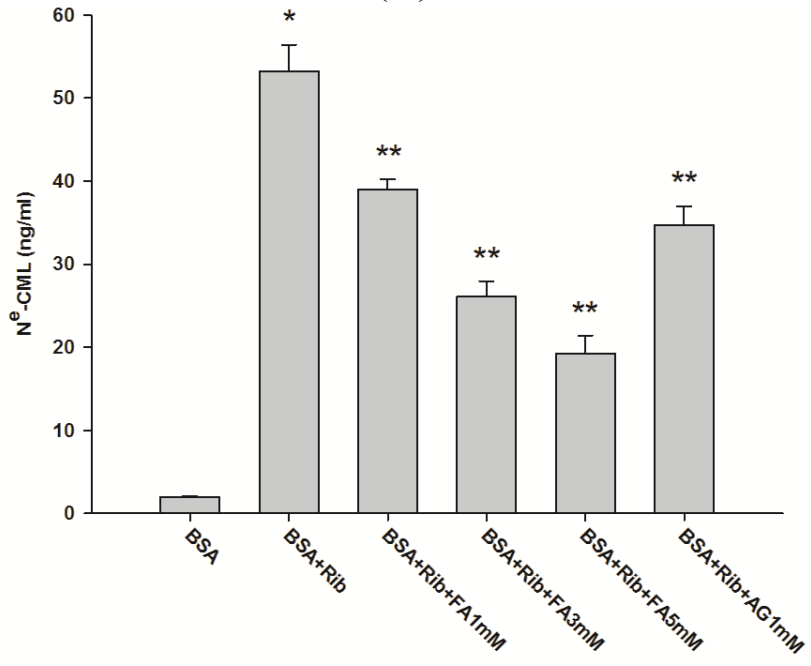


As shown in Figure 4, the level of fructosamine in BSA incubated with glucose, fructose, and ribose increased by 41.57-, 9.59-, and 68.12-fold respectively compared to non-glycated BSA. The results demonstrated that ribose exhibited the highest rate of fructosamine production among the three monosaccharides. When comparing the effect of fructose and glucose on protein glycation, many reports describe that fructose has greater capability to form fluorescent and non-fluorescent AGEs than glucose $[24,25]$. Consequently, this may suggest that fructose is much more prone to produce the Amadori product (fructosamine) than glucose. However, in our study, the level of fructosamine in fructose-glycated BSA was lower than in glucose-glycated BSA.

Figure 4. Effect of FA on fructosamine level in BSA incubated with glucose (A), fructose (B) and ribose $(\mathbf{C})$ at week 4 . The results are expressed as mean $\pm \operatorname{SEM}(n=3)$. $* p<0.05$ when compared to BSA, ** $p<0.05$ when compared to BSA+glucose, $\mathrm{BSA}+$ fructose or BSA+ribose. AG was used as positive control.

(A)

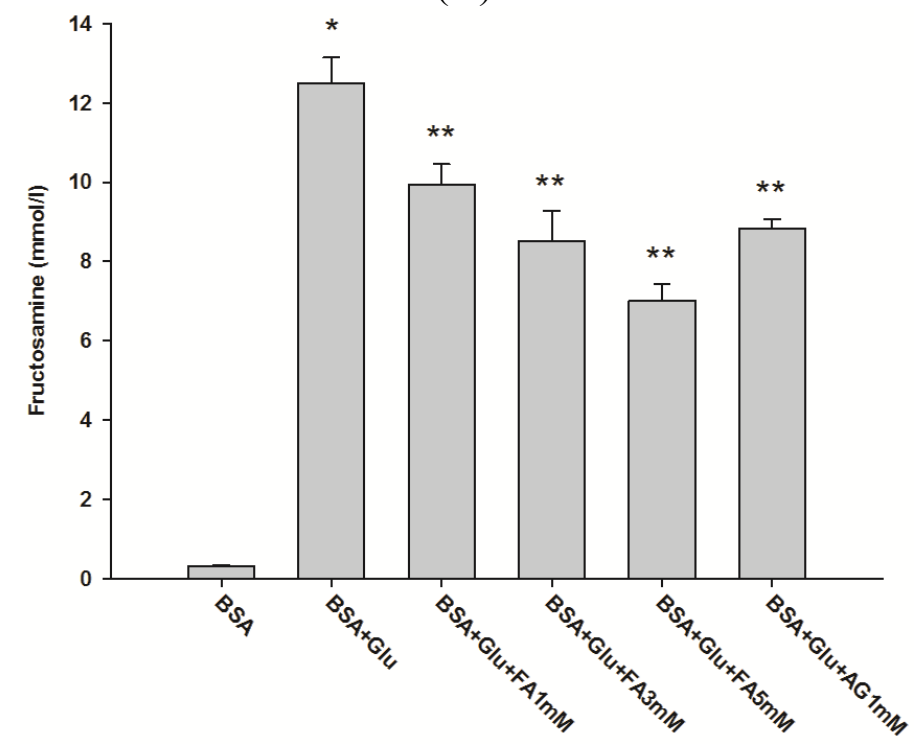

(B)

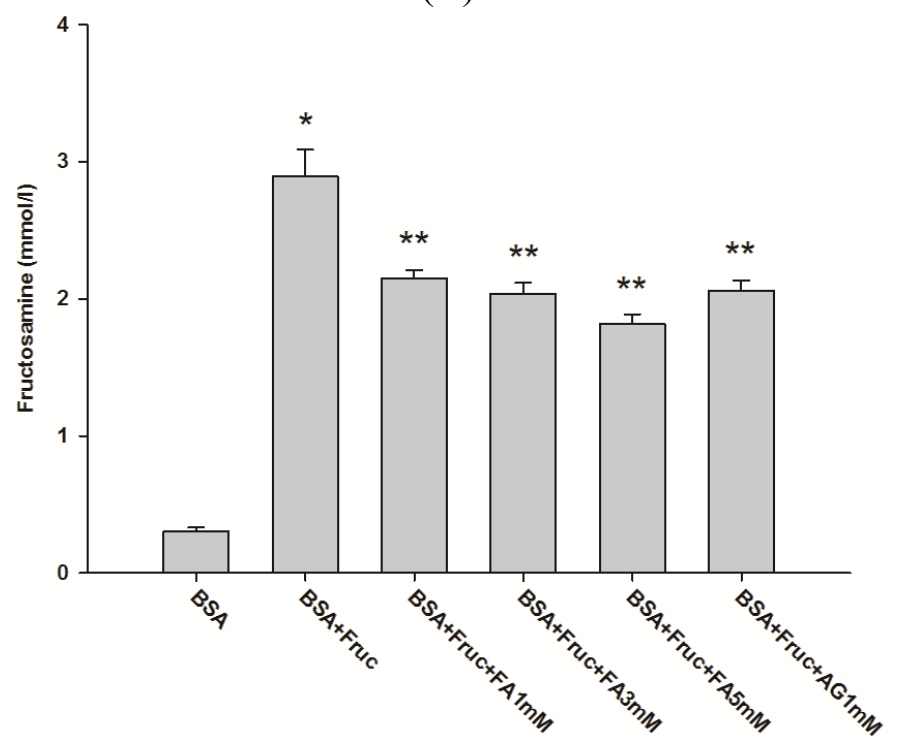


Figure 4. Cont.

(C)

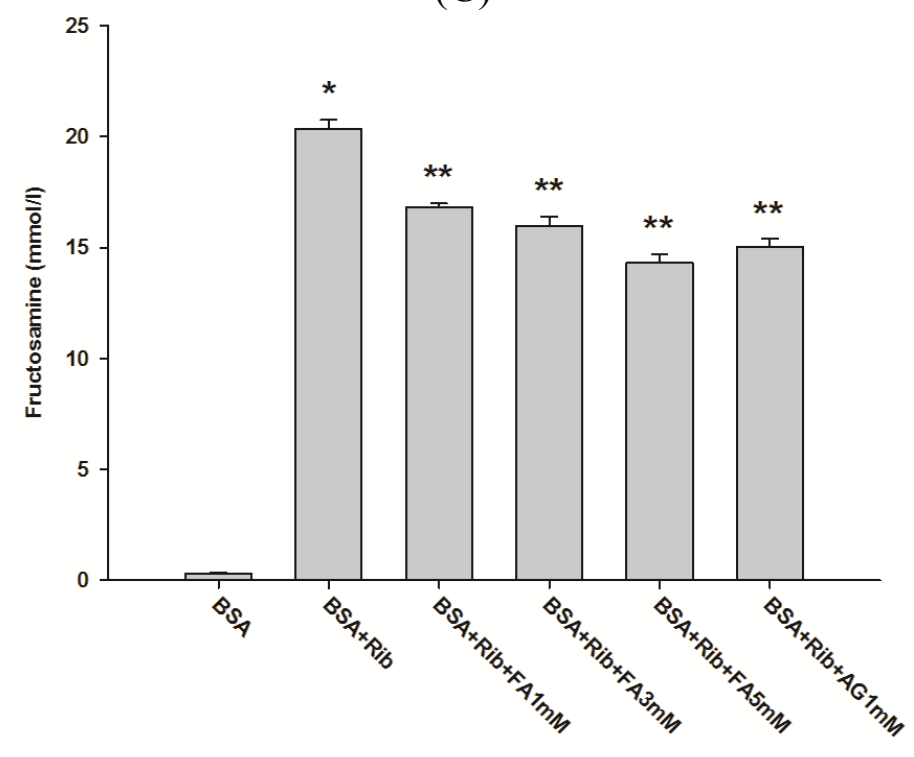

This discrepancy can be explained by the limitations of the fructosamine assay. Non-enzymatic protein glycation contributes to the difference in structure of the aldehydic and ketonic Amadori products. The level of fructosamine is commonly determined through the reaction between glycation of amino groups in BSA and a choromogenic compound nitroblue tetrazolium (NBT) under alkaline conditions. The disadvantage of the NBT assay is that aldehydic Amadori products partially react with the NBT redox dyes [26]. This may be the reason for underestimating fructosamine levels in fructose-glycated BSA.

Furthermore, FA (1-5 mM) showed a significant reduction in fructosamine levels in glucose-glycated BSA (20.45\%-43.81\%), fructose-glycated BSA $(25.17 \%-36.92 \%)$, and ribose-glycated BSA (17.34\%-29.71\%). According to these results, it can be suggested that FA inhibits the formation of fluorescent and non-fluorescent AGEs associated with reduced fructosamine levels. In addition, AG (1 $\mathrm{mM})$ demonstrated a significant reduction in fructosamine, since the percentages of fructosamine reduction of glucose-, fructose-, and ribose-glycated BSA were $29.09 \%, 28.56 \%$, and $26.21 \%$, respectively. Comparison of the percentage inhibition showed that FA (1 mM) was less effective than AG (1 mM) in the reduction of fructosamine in glucose-, fructose-, and ribose-glycated BSA. It is proposed that blockage of carbonyl or dicarbonyl groups in monosaccharides, Schiff's bases or Amadori products can be used as a strategy to inhibit protein glycation [4]. AG acts as a carbonyl trapping agent by forming guanidine-dicarbonyl adducts, thereby reducing the number of free carbonyl groups in reducing sugars during the early stages of glycation [27].

\subsection{Effect of Ferulic Acid on Protein Aggregation}

The levels of amyloid cross $\beta$-structures in BSA incubated with the three monosaccharides are presented in Figure 5. After four weeks of incubation, the fluorescence intensity of glucose-, fructose-, ribose-glycated BSA significantly increased to 1.50-, 3.37- and 5.92-fold over the fluorescence intensity of non-glycated BSA. The addition of FA into the reaction caused a significant decrease in 
amyloid cross $\beta$-structure levels in BSA, ranging from $17.84 \%$ to $34.54 \%$ (glucose), $27.25 \%$ to $39.51 \%$ (fructose), and $8.26 \%$ to $59.92 \%$ (ribose). A significant decrease in amyloid cross $\beta$-structure levels ( $12.87 \%$ in BSA+glucose, $6.39 \%$ in BSA+fructose, and $33.71 \%$ in BSA+ribose) was observed in the presence of AG $(1 \mathrm{mM})$. Comparatively, the ability to reduce protein aggregation in glucose-glycated and fructose-glycated BSA by ferulic acid $(1 \mathrm{mM})$ was higher than $\mathrm{AG}(1 \mathrm{mM})$. However, the percentage reduction of ribose-glycated BSA by FA was less than AG.

Figure 5. Effect of FA on amyloid cross $\beta$-structure levels in BSA incubated with glucose $(A)$, fructose $(\mathbf{B})$ and ribose $(\mathbf{C})$ at week 4 . The results are expressed as mean $\pm \operatorname{SEM}(n=3)$. $* p<0.05$ when compared to BSA, ** $p<0.05$ when compared to $\mathrm{BSA}+$ glucose, $\mathrm{BSA}+$ fructose or BSA+ribose. AG was used as positive control.

(A)

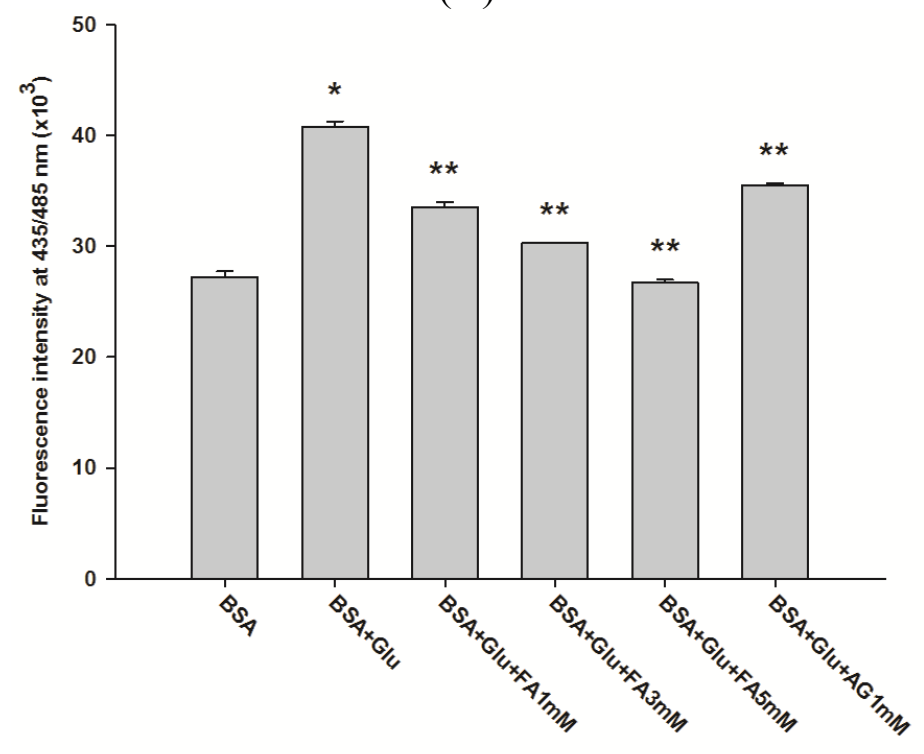

(B)

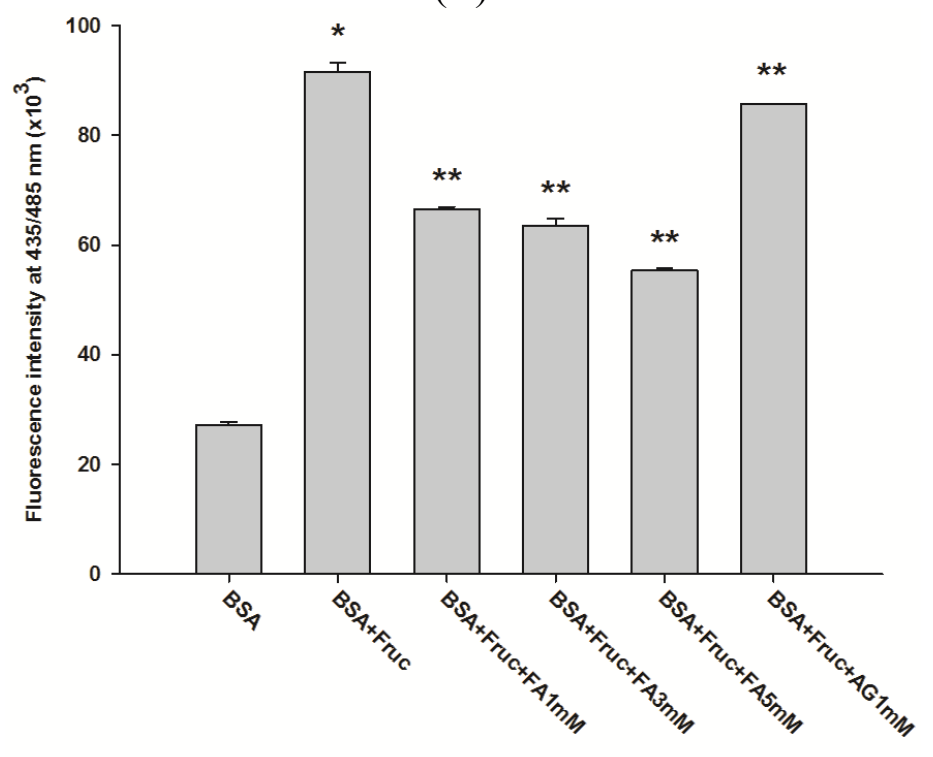


Figure 5. Cont.

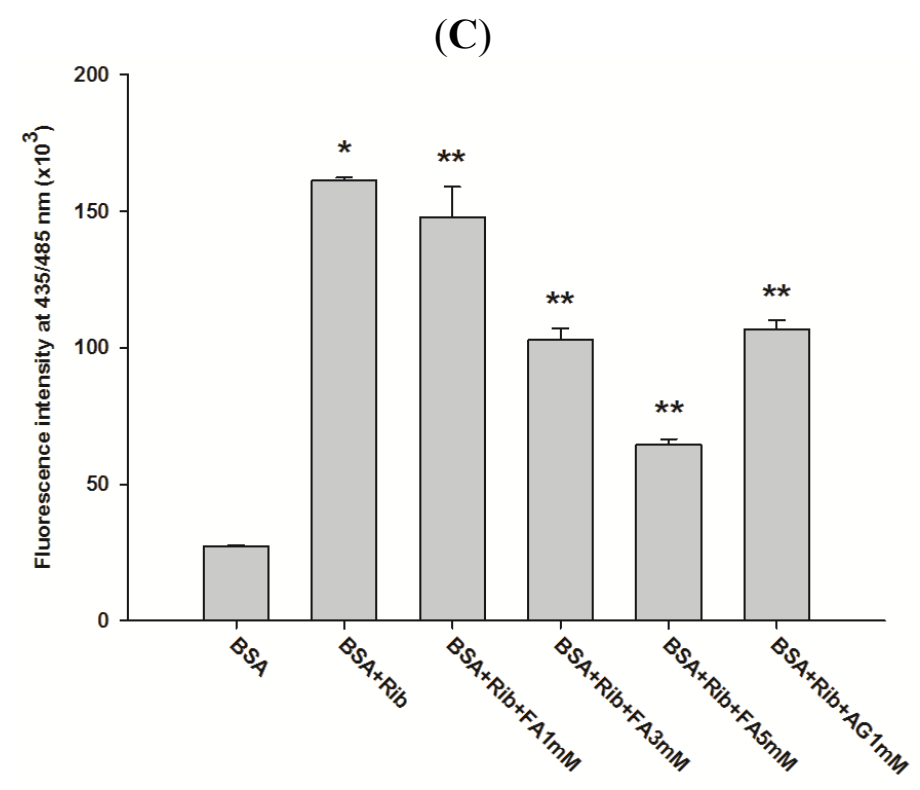

Protein glycation is believed to be a key mechanism to accelerate the formation of protein aggregation and amyloid cross $\beta$-structures leading to altered protein structure and stability $[28,29]$. The long-term accumulation of amyloid cross $\beta$-structures in tissues and organs is linked to the progression of pancreatic islet amyloidosis which directly destroys $\beta$-cell and impairs insulin secretion [30,31]. The present findings demonstrate that FA reduces the formation of amyloid cross $\beta$-structures in BSA. This beneficial effect might help reduce the risk of developing diabetes complications.

\subsection{Effect of Ferulic Acid on Protein Thiol Group and Protein Carbonyl Content}

The effect of FA on protein thiol group content in BSA incubated with the three monosaccharides is shown in Table 1. The incubation of BSA with glucose, fructose, and ribose significantly reduced the level of protein thiol groups (TO) in BSA by $18.53 \%, 28.40 \%$, and $45.09 \%$ compared to BSA alone. The results showed that FA (1-5 mM) inhibited TO loss in BSA+Glu $(6.75 \%-13.41 \%)$, BSA+Fruc (6.18\%-20.08\%), and BSA+Rib (20.50\%-39.07\%). In addition, AG (1 mM) significantly inhibited TO loss in BSA by $17.50 \%, 29.91 \%$ and $64.95 \%$ in the presence of glucose, fructose, and ribose. These results suggest that FA is less effective in the prevention of TO loss compared to AG. The effect of FA on protein carbonyl content (PCO) in BSA incubated with three monosaccharides is shown in Table 1. These results demonstrated that PCO levels in glucose-, fructose-, and ribose-glycated BSA is approximately 8.14-, 11.95- and 28.10-fold greater than non-glycated BSA. Meanwhile, FA (1-5 mM) caused a significant reduction in the protein carbonyl content level in BSA+Glu $(37.78 \%-56.03 \%)$, BSA+Fruc (36.72\%-52.74\%), and BSA+Rib (25.58\%-33.46\%). Similarly, a significant decrease in PCO level $(42.75 \%$ in BSA+Glu, $40.57 \%$ in BSA+Fruc, and $31.31 \%$ in BSA+Rib) was observed in the presence of AG $(1 \mathrm{mM})$. Comparing the percent reduction in PCO at concentration of $1 \mathrm{mM}$, FA was more effective than AG only against glucose-mediated protein glycation. 
Table 1. Effect of FA on protein thiol group and protein carbonyl content in BSA incubated with glucose, fructose, and ribose at week 4. AG was used as positive control. The results are expressed as mean $\pm \operatorname{SEM}(n=3) . * p<0.05$ when compared to BSA, $* * p<0.05$ when compared to BSA+Glucose, BSA+Fructose or BSA+Ribose.

\begin{tabular}{ccc}
\hline Experimental groups & $\begin{array}{c}\text { Protein thiol group } \\
\text { (nmol/mg protein) }\end{array}$ & $\begin{array}{c}\text { Protein carbonyl content } \\
\text { (nmol/mg protein) }\end{array}$ \\
\hline BSA & $0.92 \pm 0.03$ & $0.26 \pm 0.04$ \\
BSA+Glu & $0.75 \pm 0.02 *$ & $2.03 \pm 0.06 *$ \\
BSA+Glu+FA 1 mM & $0.80 \pm 0.02$ & $1.26 \pm 0.04 * *$ \\
BSA+Glu+FA 3 mM & $0.83 \pm 0.02$ & $1.07 \pm 0.03 * *$ \\
BSA+Glu+FA 5 mM & $0.85 \pm 0.03$ & $0.89 \pm 0.04 * *$ \\
BSA+Glu+AG 1 mM & $0.88 \pm 0.02 * *$ & $1.16 \pm 0.06 * *$ \\
BSA+Fruc & $0.66 \pm 0.03 *$ & $2.98 \pm 0.08 *$ \\
BSA+Fruc+FA 1 mM & $0.70 \pm 0.03$ & $1.88 \pm 0.04 * *$ \\
BSA+Fruc+FA 3 mM & $0.74 \pm 0.01$ & $1.68 \pm 0.06 * *$ \\
BSA+Fruc+FA 5 mM & $0.79 \pm 0.02$ & $1.41 \pm 0.03 * *$ \\
BSA+Fruc+AG 1 mM & $0.85 \pm 0.04 * *$ & $1.77 \pm 0.06 * *$ \\
BSA+Rib & $0.50 \pm 0.01 *$ & $6.97 \pm 0.09 *$ \\
BSA+Rib+FA 1 mM & $0.61 \pm 0.02$ & $5.19 \pm 0.09 * *$ \\
BSA+Rib+FA 3 mM & $0.66 \pm 0.05 * *$ & $4.93 \pm 0.07 * *$ \\
BSA+Rib+FA 5 mM & $0.70 \pm 0.02 * *$ & $4.64 \pm 0.06 * *$ \\
BSA+Rib+AG 1 mM & $0.83 \pm 0.02 * *$ & $4.79 \pm 0.06 * *$ \\
\hline
\end{tabular}

Thiol groups of proteins are a general target to determine the protein oxidation during glycation $[32,33]$. Cysteine and methionine are particularly prone to oxidative attack by free radical species such as superoxide and hydroxyl radicals. The direct oxidation of amino acid (Lys, Arg, Thr) or secondary reaction of amino acid residues (Cys and His) with reactive carbonyl compounds can produce the formation of PCO derivatives [34]. Hence, the protein carbonyl content is commonly used as a marker for protein oxidative damage [35]. The formation of AGEs is a multifactorial process. One of the mechanisms of AGEs formation and protein damage is through the production of reactive oxygen species (ROS). It is well established that protein glycation continually generates superoxide anions from early glycation products that include 1,2- and 2,3-enolization of the Schiff's base and oxidation of the enolate anion [36,37]. In addition, the Amadori product or Schiff's base undergoes fragmentation through reactive oxygen species-mediated reactions to generate short-chain carbohydrate intermediates, which alter lysine and arginine residues to produce AGEs. According to the formation of non-fluorescent and non-crosslinking structures so far, hydroxyl radicals generated by Fenton reactions between $\mathrm{Fe}^{2+}$ and Amadori product-derived endogenous $\mathrm{H}_{2} \mathrm{O}_{2}$ causes oxidative cleavage of Amadori compounds into $\mathrm{N}^{\varepsilon}$-CML [38]. This mechanism is involved in the defense against free radical attack on proteins [4]. Like many polyphenols, FA exhibits antioxidant activity by scavenging superoxide and hydroxyl radicals, suggesting that inhibition of protein glycation and AGE formation may be related to its antioxidant activity [39,40]. The results showed that FA can be as effective as AG for suppression of protein glycation. Unfortunately, AG was discontinued in Phase III clinical trials possibly due to its toxicity [41]. FA present in fruits and vegetables is considered to be a non-toxic compound that can be 
absorbed and metabolized in the body. Data on the bioavailability of FA ranges from $0.4 \%$ to 98\% [42]. Based on the current knowledge, FA could be a promising inhibitor of AGE formation.

\subsection{Correlation Coefficients between Glycation and Protein Oxidation}

Table 2 shows the Pearson's coefficients $(r)$ with the correlation between protein glycation and protein oxidation of BSA incubated with the three monosaccharides and FA.

Table 2. Pearson's correlation coefficients of fluorescence AGEs (F-AGEs), $N^{\varepsilon}-\mathrm{CML}$, fructosamine (Frc), amyloid cross $\beta$-structure (Amy), protein carbonyl content (PCO), and protein thiol group (TO) level in BSA incubated with the three types of monosaccharides and FA.

\begin{tabular}{ccccccc}
\hline & F-AGEs & $\mathbf{N}^{\varepsilon}-\mathbf{C M L}$ & Frc & Amy & PCO & TO \\
\hline F-AGEs & - & $0.987 *$ & $0.826 *$ & $0.904 *$ & $0.978 *$ & $-0.826 *$ \\
N $^{\varepsilon}$-CML & - & - & $0.806 *$ & $0.919 *$ & $0.956 *$ & $-0.806 *$ \\
Frc & - & - & - & $0.572 *$ & $0.787 *$ & $-0.512 *$ \\
Amy & - & - & - & - & $0.896 *$ & $-0.876 *$ \\
PCO & - & - & - & - & - & $-0.845 *$ \\
TO & - & - & - & - & - & - \\
\hline
\end{tabular}

* Significant at $p<0.001$.

The level of non-fluorescent AGEs ( $\left.\mathrm{N}^{\varepsilon}-\mathrm{CML}\right)$, fructosamine, amyloid cross $\beta$-structure, and protein carbonyl content exhibited a positive correlation with the level of fluorescent AGEs (Figure 6). This suggests that the reduction in fluorescent AGEs in glucose-, fructose-, and ribose-glycated BSA by FA was directly proportional to the level of non-fluorescent AGEs $\left(\mathrm{N}^{\varepsilon}-\mathrm{CML}\right)$, fructosamine, amyloid cross $\beta$-structure, and protein carbonyl content. Conversely, there was a negative correlation between the level of fluorescent AGEs and protein thiol group, suggesting that FA caused a decrease in the levels of fluorescent AGEs in glucose-, fructose-, and ribose-glycated BSA that was inversely proportional to the level of protein thiol group in glycated BSA. A positive correlation between the level of non-fluorescent AGEs $\left(\mathrm{N}^{\varepsilon}\right.$-CML), fructosamine, amyloid cross $\beta$-structure, and protein carbonyl content and a negative correlation between the level of non-fluorescent AGEs $\left(\mathrm{N}^{\varepsilon}-\mathrm{CML}\right)$ and protein thiol group were observed with all three monossaccharides. Interestingly, the level of fructosamine exhibited a positive and negative correlation with the levels of amyloid cross $\beta$-structure and protein thiol groups, respectively.

\section{Experimental}

\subsection{Chemicals}

Bovine serum albumin (BSA, fraction V), ferulic acid (FA, 4-hydroxy-3-methoxycinnamic acid), aminoguanidine hydrochloride (AG), D-ribose, nitroblue tetrazolium (NBT), 1-deoxy-1-morpholino-Dfructose (1-DMF), guanidine hydrochloride, thioflavin T, 5,5'-dithiobis(2-nitrobenzoic acid) (DTNB) and L-cysteine were purchased from Sigma-Aldrich Co. (St. Louis, MO, USA). D-Glucose, D-fructose and 2,4-dinitrophenyl hydrazine (DNPH) were purchased from Ajax Finechem (Taren Point, Australia). 
Trichloroacetic acid (TCA) was purchased from Merck (Darmstadt, Germany). OxiSelect ${ }^{\mathrm{TM}}$ $\mathrm{N}^{\varepsilon}$-(carboxymethyl) lysine $\left(\mathrm{N}^{\varepsilon}\right.$-CML) ELISA kit was obtained from Cell Biolabs (San Diego, CA, USA). All other chemicals and solvents used in this study were analytical grade.

Figure 6. Correlations between fluorescent AGEs (F-AGEs), $\mathrm{N}^{\varepsilon}$-CML, fructosamine (Fruc), amyloid cross $\beta$-structure (Amy), protein carbonyl content (PCO), and thiol group (TO) in the BSA containing glucose, fructose, and ribose and various concentrations of FA $(1-5 \mathrm{mM})$.

(A)

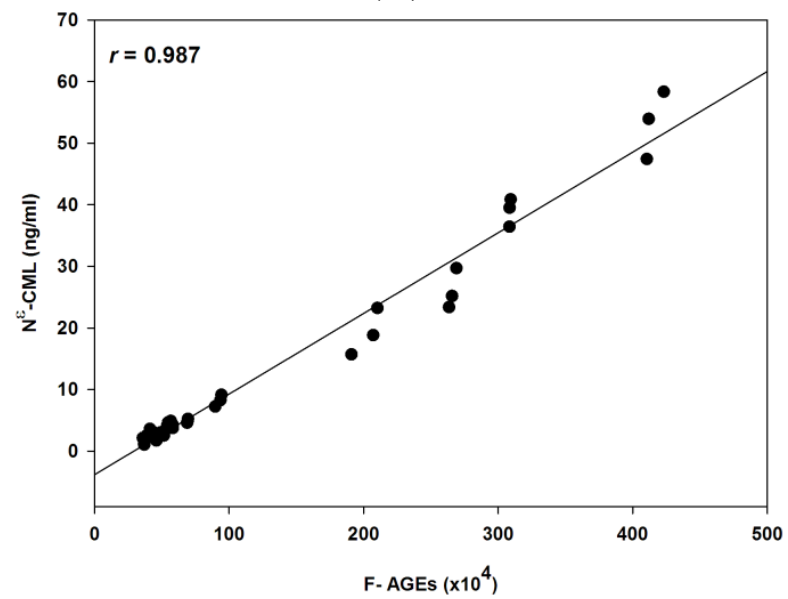

(C)

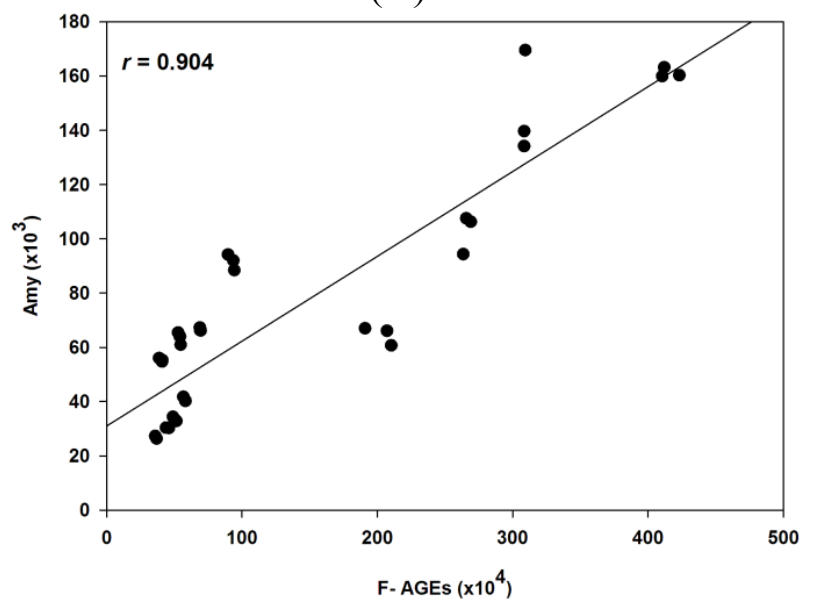

(B)

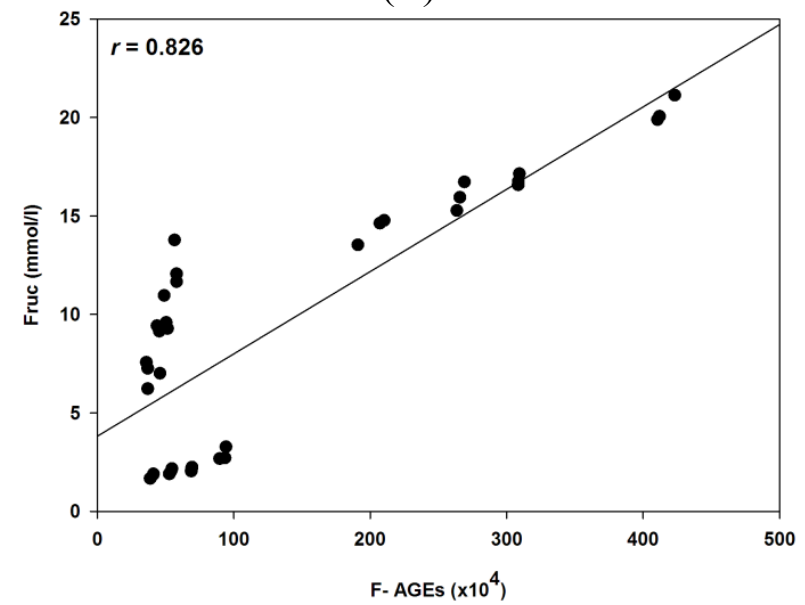

(D)

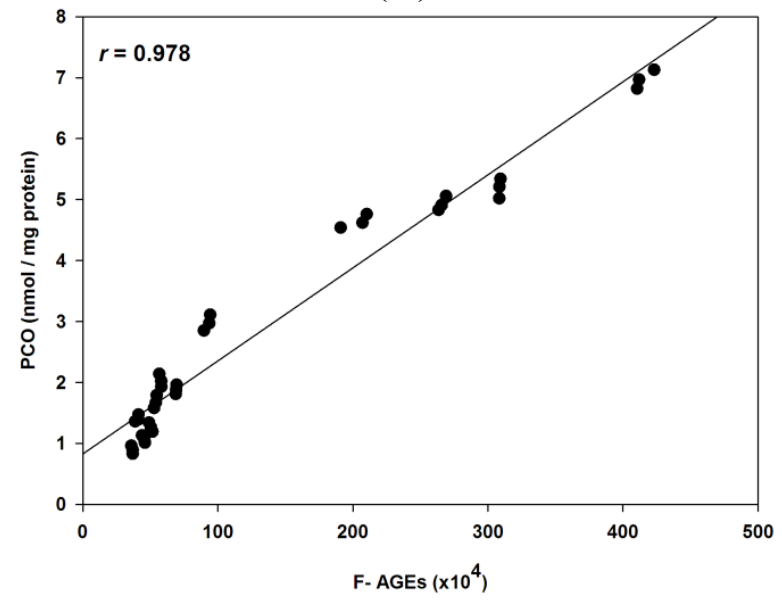

(E)

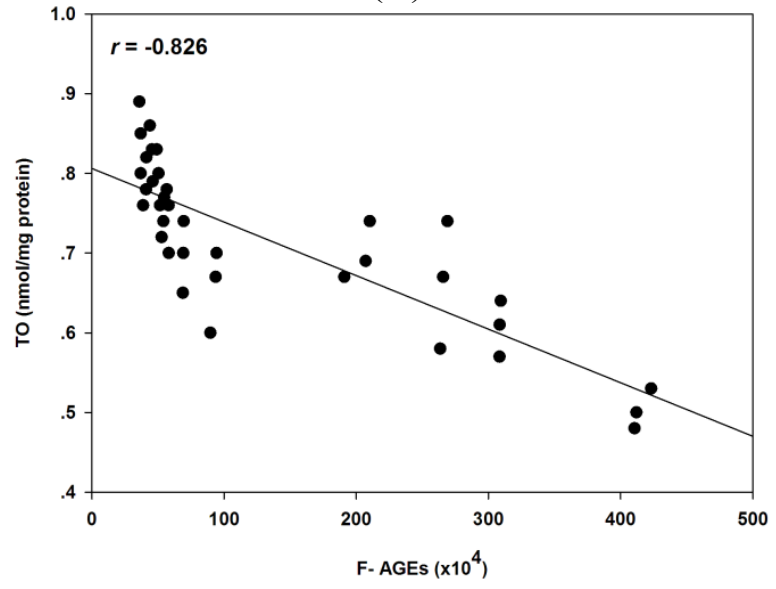




\subsection{In Vitro Glycation of Bovine Serum Albumin (BSA) Induced by Monosaccharides}

Glycation of BSA was done according to a previous method with minor modifications [43]. Briefly, $10 \mathrm{mg} / \mathrm{mL}$ BSA was incubated with $500 \mathrm{mM}$ glucose, $500 \mathrm{mM}$ fructose and $100 \mathrm{mM}$ ribose in $100 \mathrm{mM}$ phosphate buffered-saline ( $\mathrm{pH} 7.4$ ) containing $0.02 \%$ sodium azide at $37{ }^{\circ} \mathrm{C}$ for four weeks in the absence or presence of FA and AG (a positive control). Before incubation, FA (final concentration: 1, 3, and $5 \mathrm{mM}$ ) and $\mathrm{AG}$ (final concentration: $1 \mathrm{mM}$ ) were added into the reaction mixtures. A final concentration of $4 \%$ dimethylsulfoxide (DMSO) was used as solvent for the study. Samples were stored at $-20^{\circ} \mathrm{C}$ before analysis.

\subsection{Determination of Advanced Glycation End-Products (AGEs)}

The formation of fluorescent AGEs was measured using a spectrofluorometer (Wallac 1420 Victor $^{3} \mathrm{~V}$, PerkinElmer, Santa Clara, CA, USA). The fluorescence intensity was measured at an excitation wavelength of $355 \mathrm{~nm}$ and emission wavelength of $460 \mathrm{~nm}$. The concentration of non-fluorescent AGEs ( $\mathrm{N}^{\varepsilon}$-(carboxymethyl) lysine, $\mathrm{N}^{\varepsilon}$-CML), a major non-fluorescent AGE structure, was measured by using an enzyme linked immunosorbant assay (ELISA) kit according to the manufacturer's protocol. The concentration of $\mathrm{N}^{\varepsilon}-\mathrm{CML}$ was calculated by using a $\mathrm{N}^{\varepsilon}-\mathrm{CML}-\mathrm{BSA}$ standard curve.

\subsection{Determination of Fructosamine (Amadori Products)}

The level of Amadori products was measured as fructosamine by using nitroblue-tetrazolium (NBT) dye according to a previous method with minor modifications [44]. Glycated BSA was incubated with $0.5 \mathrm{mM}$ NBT in $100 \mathrm{mM}$ carbonate buffer $\left(\mathrm{pH} \mathrm{10.4)}\right.$ at $37^{\circ} \mathrm{C}$. The absorbance was measured at $530 \mathrm{~nm}$. The level of fructosamine was calculated using the different absorption at the time point of 10 and $15 \mathrm{~min}$, and compared to 1-deoxy-1-morpholino-D-fructose (1-DMF) as the standard.

\subsection{Determination of Protein Aggregation}

Amyloid cross $\beta$-structure, a common marker for protein aggregation was measured using the thioflavin $\mathrm{T}$ assay according to a previous method with minor modifications [45]. Glycated BSA was incubated with $32 \mu \mathrm{M}$ thioflavin $\mathrm{T}$ in $100 \mathrm{mM}$ phosphate buffered-saline (pH 7.4) at room temperature for $60 \mathrm{~min}$. The fluorescence intensity was measured at an excitation wavelength of $435 \mathrm{~nm}$ and emission wavelength of $485 \mathrm{~nm}$.

\subsection{Determination of Protein Thiol Group}

Protein thiol group was measured according to Ellman's assay with minor modifications [46]. Glycated BSA was incubated with $5 \mathrm{mM}$ 5,5'-dithiobis(2-nitrobenzoic acid) (DTNB) in $100 \mathrm{mM}$ phosphate buffered-saline ( $\mathrm{pH} \mathrm{7.4)}$ at room temperature for $15 \mathrm{~min}$ and the absorbance measured at $412 \mathrm{~nm}$. The level of protein thiol group was calculated from a standard curve prepared using L-cysteine. The results were expressed as nmol L-cysteine/mg protein. 


\subsection{Determination of Protein Carbonyl Content}

Protein carbonyl content, a common marker for protein oxidative damage, was measured according to a previous method with minor modifications [47]. Glycated BSA was incubated with $10 \mathrm{mM}$ 2,4-dinitrophenylhydrazine (DNPH) in $2.5 \mathrm{M} \mathrm{HCl}$ at room temperature for $60 \mathrm{~min}$. Afterwards, it was precipitated by $20 \%(\mathrm{w} / \mathrm{v})$ trichloroacetic acid (TCA), left on ice for $5 \mathrm{~min}$, and centrifuged at 10,000 $\mathrm{g}$ at $4{ }^{\circ} \mathrm{C}$ for $10 \mathrm{~min}$. The pellet was washed three times using $1: 1(\mathrm{v} / \mathrm{v})$ ethanol-ethyl acetate mixture. The final pellet was dissolved in $6 \mathrm{M}$ guanidine hydrochloride. The absorbance was recorded at $370 \mathrm{~nm}$. The level of protein carbonyl content was calculated by using an absorption coefficient of $22,000 \mathrm{M}^{-1} \mathrm{~cm}^{-1}$. The results were expressed as nmol carbonyls/mg protein.

\subsection{Statistical Analysis}

Data were expressed as mean \pm standard error of mean (SEM). The statistical significance of the results was evaluated using one-way ANOVA. Tukey's HSD test was used to analyze the differences between the means. $p<0.05$ was considered to be statistically significant.

\section{Conclusions}

For the first time, FA was evaluated for its inhibitory effects against three monosaccharidemediated protein glycation reactions and oxidative damage of BSA. Using in vitro models, FA markedly inhibited protein glycation and oxidative damage in BSA induced by glucose, fructose, and ribose. Consequently, FA decreased the formation of fluorescent AGEs, non-fluorescent AGEs and fructosamine associated with the reduction of protein aggregation and protein carbonyl content. It also prevented the loss of protein thiol groups. Given the ability of FA to inhibit monosaccharide-mediated protein glycation and oxidation, our findings could be potentially useful in the prevention of AGE-mediated pathologies during diabetic complications.

\section{Acknowledgments}

The authors wish to thank the Chula Dusadee Pipat Scholarships, and the Asia Research Center, Chulalongkorn University for financial support in this study. The authors would also like to thank The Medical Food Research and Development Center, and Research Group of Herbal Medicine for Prevention and Therapeutic of Metabolic diseases which have been financially and institutionally supported by Chulalongkorn University.

\section{Conflicts of Interest}

The authors declare no conflict of interest.

\section{References}

1. Baynes, J.W.; Watkins, N.G.; Fisher, C.I.; Hull, C.J.; Patrick, J.S.; Ahmed, M.U.; Dunn, J.A.; Thorpe, S.R. The Amadori product on protein: Structure and reactions. Prog. Clin. Biol. 1989, 304, 43-67. 
2. Booth, A.A.; Khalifah, R.G.; Todd, P.; Hudson, B.G. In vitro kinetic studies of formation of antigenic advanced glycation end products (AGEs). Novel inhibition of post-Amadori glycation pathways. J. Biol. Chem. 1997, 272, 5430-5437.

3. Cohen, G.; Riahi, Y.; Alpert, E.; Gruzman, A.; Sasson, S. The roles of hyperglycaemia and oxidative stress in the rise and collapse of the natural protective mechanism against vascular endothelial cell dysfunction in diabetes. Arch. Physiol. Biochem. 2007, 113, 259-267.

4. Wu, C.H.; Huang, S.M.; Lin, J.A.; Yen, G.C. Inhibition of advanced glycation endproduct formation by foodstuffs. Food Funct. 2011, 2, 224-234.

5. Ahmed, N. Advanced glycation endproducts-role in pathology of diabetic complications. Diabetes Res. Clin. Pract. 2005, 67, 3-21.

6. Brownlee, M. Advanced protein glycosylation in diabetes and aging. Annu. Rev. Med. 1995, 46, 223-234.

7. Schmidt, A.M.; Stern, D. Atherosclerosis and diabetes: The RAGE connection. Curr. Atheroscler. Rep. 2000, 2, 430-436.

8. Vitek, M.P.; Bhattacharya, K.; Glendening, J.M.; Stopa, E.; Vlassara, H.; Bucala, R.; Manogue, K.; Ceremi, A. Advanced glycation end products contribute to amyloidosis in Alzheimer disease. Proc. Natl. Acad. Sci. USA 1994, 91, 4766-4770.

9. Ledesma-Osuna, A.I.; Ramos-Clamont, G.; Vazquez-Moreno, L. Characterization of bovine serum albumin glycated with glucose, galactose and lactose. Acta Biochim. Pol. 2008, 55, 491-497.

10. Wei, Y.; Chen, L.; Chen, J.; Ge, L.; He, R.Q. Rapid glycation with D-ribose induces globular amyloid-like aggregations of BSA with high cytotoxicity to SH-SY5Y cells. BMC Cell Biol. 2009, 10, 10.

11. Adisakwattana, S.; Moonsan, P.; Yibchok-Anun, S. Insulin-releasing properties of a series of cinnamic acid derivatives in vitro and in vivo. J. Agric. Food Chem. 2008, 56, 7838-7844.

12. Adisakwattana, S.; Chantarasinlapin, P.; Thammarat, H.; Yibchok-Anun, S. A series of cinnamic acid derivatives and their inhibitory activity on intestinal $\alpha$-glucosidase. J. Enzyme Inhib. Med. Chem. 2009, 24, 1194-1200.

13. Wang, J.; Sun, B.; Cao, Y.; Tian, Y. Protein glycation inhibitory activity of wheat bran feruloyl oligosaccharides. Food Chem. 2009, 112, 350-353.

14. Srey, C.; Hull, G.L.; Connolly, L.; Elliott, C.T.; del Castillo, M.D.; Ames, J.M. Effect of inhibitor compounds on $\mathrm{N}^{\varepsilon}$-(carboxymethyl)lysine (CML) and $\mathrm{N}^{\varepsilon}$-(carboxyethyl)lysine (CEL) formation in model foods. J. Agric. Food Chem. 2010, 58, 12036-12041.

15. Srey, C.; Haughey, S.A.; Connolly, L.; del Castillo, M.D.; Ames, J.M.; Elliott, C.T. Immunochemical and mass spectrometric analysis of $\mathrm{N}^{\varepsilon}$-(carboxymethyl)lysine content of AGE-BSA systems prepared with and without selected antiglycation agents. J. Agric. Food Chem. 2010, 58, 11955-11961.

16. McPherson, J.D.; Shilton, B.H.; Walton, D.J. Role of fructose in glycation and cross-linking of proteins. Biochemistry 1988, 27, 1901-1907.

17. Monnier, V.M. Nonenzymatic glycosylation, the Maillard reaction and the aging process. J. Gerontol. 1990, 45, B105-B111.

18. Silvan, J.M.; Assar, S.H.; Srey, C.; Dolores del Castillo, M.; Ames, J.M. Control of the Maillard reaction by ferulic acid. Food Chem. 2011, 128, 208-213. 
19. Hinton, D.; Ames, J. Site specificity of glycation and carboxymethylation of bovine serum albumin by fructose. Amino Acids 2006, 30, 425-434.

20. Vukasovi, D.; Jureti, D. Enzyme activity and AGE formation in a model of AST glycoxidation by D-fructose in vitro. Acta Pharm. 2005, 55, 107-114.

21. Adisakwattana, S.; Sompong, W.; Meeprom, A.; Ngamukote, S.; Yibchok-anun, S. Cinnamic acid and its derivatives inhibit fructose-mediated protein glycation. Int. J. Mol. Sci. 2012, 13, 1778-1789.

22. Gugliucci, A.; Bastos, D.H.; Schulze, J.; Souza, M.F. Caffeic and chlorogenic acids in Ilex paraguariensis extracts are the main inhibitors of AGE generation by methylglyoxal in model proteins. Fitoterapia 2009, 80, 339-344.

23. Wu, C.H.; Huang, H.W.; Lin, J.A.; Huang S.M.; Yen, G.C. The proglycation effect of caffeic acid leads to the elevation of oxidative stress and inflammation in monocytes, macrophages and vascular endothelial cells. J. Nutr. Biochem. 2011, 22, 585-594.

24. Meeprom, A.; Sompong, W.; Chan, C.B.; Adisakwattana, S. Isoferulic Acid, a new anti-glycation agent, inhibits fructose-and glucose-mediated protein glycation in vitro. Molecules 2013, 18 , 6439-6454.

25. Suarez, G.; Rajaram, R.; Oronsky, A.; Gawinowicz, M. Nonenzymatic glycation of bovine serum albumin by fructose (fructation). Comparison with the Maillard reaction initiated by glucose. J. Biol. Chem. 1989, 264, 3674-3679.

26. Ahmed, N.; Furth, A.J. Failure of common glycation assays to detect glycation by fructose. Clin. Chem. 1992, 38, 1301-1303.

27. Foiles, P.G.; Founds, H.W.; Vasan, S. Therapeutic potential of AGE inhibitors and breakers of AGE protein cross-links. Expert Opin. Invest. Drugs. 2001, 10, 1977-1987.

28. Bouma, B.; Kroon-Batenburg, L.M.; Wu, Y.P.; Brunjes, B.; Posthuma, G.; Kranenburg, O.; de Groot, P.G.; Voest, E.E.; Gebbink, M.F. Glycation induces formation of amyloid cross-beta structure in albumin. J. Biol. Chem. 2003, 278, 41810-41819.

29. Luthra, M.; Balasubramanian, D. Nonenzymatic glycation alters protein structure and stability. A study of two eye lens crystallins. J. Biol. Chem. 1993, 268, 18119-18127.

30. Tokuyama, T.; Yagui, K.; Yamaguchi, T.; Huang, C.I.; Kuramoto, N.; Shimada, F.; Miyazaki, J.; Horie, H.; Saito, Y.; Makino, H.; et al. Expression of human islet amyloid polypeptide/amylin impairs insulin secretion in mouse pancreatic beta cells. Metabolism 1997, 46, 1044-1051.

31. Marzban, L.; Verchere, C.B., The role of islet amyloid polypeptide in type 2 diabetes. Can. J. Diabetes 2004, 28, 39-47.

32. Zeng, J.; Davies, M.J. Protein and low molecular mass thiols as targets and inhibitors of glycation reactions. Chem. Res. Toxicol. 2006, 19, 1668-1676.

33. Acimovic, J.M.; Stanimirovic, B.D.; Mandic, L.M. The role of the thiol group in protein modification with methylglyoxal. J. Serb. Chem. Soc. 2009, 74, 867-883.

34. Dalle-Donne, I.; Giustarini, D.; Colombo, R.; Rossi, R.; Milzani, A. Protein carbonylation in human diseases. Trends Mol. Med. 2003, 9, 169-176.

35. Dalle-Donne, I.; Rossi, R.; Giustarini, D.; Milzani, A.; Colombo, R. Protein carbonyl groups as biomarkers of oxidative stress. Clin. Chim. Acta 2003, 329, 23-38.

36. Carubelli, R.; Schneider, J.E.; Pye, Q.N.; Floyd, R.A. Cytotoxic effects of autoxidative glycation. Free Radic. Biol. Med. 1995, 18, 265-269. 
37. Smith, P.R.; Thornalley, P.J. Mechanism of the degradation of non-enzymatically glycated proteins under physiological conditions. Eur. J. Biochem. 1992, 210, 729-739.

38. Nagai, R.; Ikeda, K.; Higashi, T.; Sano, H.; Jinnouchi, Y.; Araki, T.; Horiuchi, S. Hydroxyl Radical Mediates $\mathrm{N}^{\epsilon}$-(Carboxymethyl) lysine Formation from Amadori Product. Biochem. Biophys. Res. Commun. 1997, 234, 167-172.

39. Graf, E. Antioxidant potential of ferulic acid. Free Radic. Biol. Med. 1992, 13, 435-448.

40. Ogiwara, T.; Satoh, K.; Kadoma, Y.; Murakami, Y.; Unten, S.; Atsumi, T.; Sakagami, H.; Fujisawa, S. Radical scavenging activity and cytotoxicity of ferulic acid. Anticancer Res. 2001, 22, 2711-2717.

41. Peyroux, J.; Sternberg, M. Advanced glycation endproducts (AGEs): Pharmacological inhibition in diabetes. Pathol. Biol. 2006, 54, 405-419.

42. Mateo Anson, N.; van den Berg, R.; Havenaar, R.; Bast, A.; Haenen, G.R. Bioavailability of ferulic acid is determined by its bioaccessibility. J. Cereal Sci. 2009, 49, 296-300.

43. Adisakwattana, S.; Jiphimai, P.; Prutanopajai, P.; Chanathong, B.; Sapwarobol, S.; Ariyapitipan, T. Evaluation of $\alpha$-glucosidase, $\alpha$-amylase and protein glycation inhibitory activities of edible plants. Int. J. Food Sci. Nutr. 2010, 61, 295-305.

44. Johnson, R.N.; Metcalf, P.A.; Baker, J.R. Fructosamine: A new approach to the estimation of serum glycosylprotein. An index of diabetic control. Clin. Chim. Acta 1983, 127, 87-95.

45. Le Vine, H. Quantification of beta-sheet amyloid fibril structures with thioflavin $T$. Methods Enzymol. 1999, 309, 274-284.

46. Ellman, G.L. Tissue sulfhydryl groups. Arch. Biochem. Biophys. 1959, 82, 70-77.

47. Uchida, K.; Kanematsu, M.; Sakai, K.; Matsuda, T.; Hattori, N.; Mizuno, Y.; Suzuki, D.; Miyata, T.; Noguchi, N.; Niki, E.; Osawa, T. Protein-bound acrolein: Potential markers for oxidative stress (covalent modification of protein/antibody/atherosclerosis). Proc. Natl. Acad. Sci. USA 1998, 95, 4882-4887.

Sample Availability: Samples of the compounds are available from the authors.

(C) 2013 by the authors; licensee MDPI, Basel, Switzerland. This article is an open access article distributed under the terms and conditions of the Creative Commons Attribution license (http://creativecommons.org/licenses/by/3.0/). 